\title{
FLAME RESISTANCE AND MECHANICAL PROPERTIES OF COMPOSITES BASED ON NEW ADVANCED RESIN SYSTEM FR4/12
}

\author{
NEGORLJIVOST IN MEHANSKE LASTNOSTI KOMPOZITOV NA \\ OSNOVI NOVIH NAPREDNIH SISTEMOV SMOL FR4/12
}

\author{
Vladimír Rusnák ${ }^{1}$, Soňa Rusnáková2 ${ }^{2}$ Ladislav Fojtl², Milan Žaludek ${ }^{2}$, \\ Alexander Čapka ${ }^{2}$ \\ ${ }^{1}$ Faculty of Metallurgy and Materials Engineering, VŠB-Technical University of Ostrava, 17. listopadu 15, 70833 Ostrava-Poruba, Czech \\ Republic \\ ${ }^{2}$ Faculty of Technology, TBU in Zlín, Nad Stranemi 4511, 76005 Zlín, Czech Republic \\ vladimir.rusnak@form-composite.com
}

Prejem rokopisa - received: 2014-09-10; sprejem za objavo - accepted for publication: 2014-11-24

doi:10.17222/mit.2014.223

Composite materials used in the transport industry and also in other sectors must have a certain degree of flame resistance. For this purpose, commonly used flame retardants are based on halogen compounds in the liquid state or aluminum hydroxide in the solid state. Solid flame retardants have a negative effect on the processing and mechanical properties. Low viscosity and rapid wettability of fibers are very important, especially in an resin transfer molding (RTM) process.

Therefore, a new advanced matrix system based on phosphorus flame retardants was developed. The flame resistance and mechanical properties of the composite materials produced from the new resin system were tested. Furthermore, the processing parameters and tests are described in the article.

Keywords: flame-retardant composites, phosphorus, RTM, vacuum infusion

Kompozitni materiali, ki se uporabljajo v industriji transporta in tudi v drugih sektorjih, morajo ustrezati določeni stopnji negorljivosti. Za ta namen so splošno uporabljani zaviralci gorenja, ki temeljijo na osnovi spojin halogenov v tekočem stanju ali na aluminijevem hidroksidu v trdnem stanju. Zaviralci gorenja v trdnem stanju imajo negativen vpliv na izdelavo in mehanske lastnosti. Posebno majhna viskoznost in hitra omočljivost vlaken sta pomembni, posebno še pri RTM-procesu.

Zato je bila razvita nova napredna matrična zasnova na podlagi fosfornega zaviralca gorenja. Preizkušene so bile odpornost proti vžigu in mehanske lastnosti kompozitnega materiala, izdelanega iz novega sistema smol. V članku so opisani parametri izdelave in preizkusi.

Ključne besede: negorljivi kompoziti, fosfor, RTM, vakuumska infuzija

\section{INTRODUCTION}

Composite materials based on a polymer matrix and glass reinforcement are often used in transport vehicles. The main reasons for their utilization are their low mass, excellent formability and relatively low production costs for low and medium manufacturing series.

When composite and sandwich structures are used in train applications, they have to fulfill different requirements. The first (or the main) requirement is the fire safety. ${ }^{1}$ In addition to the fire safety of these materials, relatively high mechanical properties, dimensional and thermal stabilities and health safety are required. For example the French standard NF F01-28: Fiber reinforced plastic in railway rolling stock requires a minimum bending strength of reinforced plastics of up to 150 $\mathrm{MPa}$, while maintaining the self-extinguishing properties according to another French standard, NF F16-101.

Polyester matrices reinforced with fiber reinforcements in various forms are primarily used for these applications. In these composite systems self-extinguishing properties are primarily achieved with additions of flame retardants to the synthetic matrices.
Flame retardants are the materials that prevent or retard the burning of a material and are indispensable for plastic products, electrical applications, construction materials, textiles, etc. Generally, they can be divided into two main groups: the reactive organic and non-reactive inorganic compounds (additives). The reactive organic compounds include molecules of halogens (bromine and chlorine), melamine compounds, phosphate compounds and many others. ${ }^{2}$ Their main advantage is that they do not change the physical properties of the resin. Generally, the amount of the flame retardant in a polymer matrix depends on the retarding effect. However, it is necessary to take into account the possibility of a negative effect influencing the mechanical and processing properties of the polymer.

The reactive inorganic compounds include aluminum hydroxide (ATH) and magnesium hydroxide, red phosphorus, ammonium compounds, antimony compounds of antimony or boron, graphite, etc. ${ }^{3,4}$ These compounds are insoluble in a polymer matrix and need to be added in higher concentrations $(30-150 \%)$ to achieve the right fire-retardancy level. They have a very negative influence 
on the viscosity of the resulting mixture, thus limiting their use in the preparation of a composite with the vacuum infusion or RTM technology. And, last but not least, they negatively influence the mechanical properties - the composites become less stiff and brittle.

They slow down the combustion process in different ways, physically or chemically. The physical processes include cooling the material, creating a protective layer (that continues to protect the remaining material, blocking the combustion by limiting the access of air) or diluting the gas flame with retardant components.

With respect to the chemical processes, flame retardancy is a reaction in the gaseous phase, leading to a release of significant amounts of water or carbon dioxide. Thus, a reaction at this stage limits and slows down a burning process. This group includes the flame retardants based on halogens. These compounds create carbon ash on the polymer surface or a swelling under the protective layer of the ash to provide a better thermal insulation. ${ }^{5}$

Some flame retardants based on halogens, such as polychlorinated biphenyls (PCB), or various brominated flame retardants (polybrominated diphenyl ethers, polybrominated biphenyls) may pose a health risk. The fire retardancy of a halogenated flame retardant is based on the formation of a volatile-combustion hydrobromic or hydrochloric acid in the presence of hydrocarbons (e.g., toxic dioxins) at a temperature of around $350{ }^{\circ} \mathrm{C}$.

Flame retardants based on phosphorus are the compounds that are more environmentally friendly and their consumption is slowly growing. Phosphor flame retardants are already applied in matrices with phosphorus amounts of about 5-8\%. They work very well for the polymers containing oxygen in the chain.

\section{EXPERIMENTAL WORK}

\subsection{Materials}

\subsubsection{Matrix}

An unsaturated polyester resin diluted with styrene, containing a phosphorus flame retardant incorporated into the chain molecules was developed under the working title FR4/12 (Table 1). The goal was to prepare a resin, which enables, due to its viscosity, a preparation of the composite parts for rail vehicles using the RTM method or the vacuum infusion method. Pure resin would also meet the requirement for a flame resistance without the additives - the limited oxygen index (LOI) must be higher than 30 . The requirement for the maximum viscosity was $600 \mathrm{mPa} \mathrm{s} .^{6}$ The amount of phosphorus in the polyester chain is naturally limited since it greatly affects the mechanical properties. The resulting formulation is designed in such a way that the mechanical properties of pure resin match the mechanical properties of the halogenated resins, normally used for the production of the composite parts for rail vehicles.
Table 1: Mechanical and processing properties of FR4/12 matrix Tabela 1: Mehanski in procesni parametri osnove FR4/12

\begin{tabular}{|l|c|}
\hline \multicolumn{1}{|c|}{ Material description } & $\begin{array}{c}\text { Matrix } \\
\text { FR4/12 }\end{array}$ \\
\hline Viscosity (Brookfield LV 2/12, $\left.20^{\circ} \mathrm{C}\right)\left(\mathrm{mPa} \mathrm{s}^{6}{ }^{6}\right.$ & 475 \\
\hline$T_{\mathrm{g}} /{ }^{\circ} \mathrm{C}$ & 105 \\
\hline$H D T /{ }^{\circ} \mathrm{C}$ & 68 \\
\hline Acid number, the $\mathrm{KOH}$ content $\left(\mathrm{mg} \mathrm{g}^{-1}\right)$ & 2.5 \\
\hline Hydroxyl number, the $\mathrm{KOH}$ content $\left(\mathrm{mg} \mathrm{g}^{-1}\right)$ & 50 \\
\hline Tensile strength $(\mathrm{MPa})$ & 63 \\
\hline Tensile modulus $(\mathrm{MPa})$ & 3400 \\
\hline Elongation $(\%)$ & 2.2 \\
\hline Flexural strength $(\mathrm{MPa})$ & 3600 \\
\hline Flexural modulus $(\mathrm{MPa})$ & 130 \\
\hline Oxygen index & $32-34$ \\
\hline
\end{tabular}

\subsubsection{Reinforcements, coatings}

A multiaxial nonwoven fabric (bidiagonal and triaxial fabric) was selected as the reinforcement. A nonwoven fabric guarantees a high proportion of glass in a composite (hence, better mechanical properties). It also has a suitable drapability. In line with the requirements of the process technology, mats with the trade name UNIFILLO ${ }^{\circledR}$ were used for the RTM technology.

To determine the effect of the coating on the combustibility, two samples of the BÜFA gelcoat layer were provided.

\subsection{Production methods and testing}

The testing of the resin system was carried out at two levels. One level was the production of the test samples. These samples were produced on a simple plate or in a simple RTM mold. The second level of the matrix testing consisted of a production of real products (prototypes). Production methods were chosen with respect to the environmental, health and economic aspects (productivity), including two closed-production technologies VIP (vacuum infusion process) and RTM (resin transfer molding).

In addition to the newly produced matrix, a total of five composite materials (Table 2) of various compositions as well as other polymer systems were produced (Sample D was made from a phenolic prepreg, Sample E was based on a commercial matrix). Samples $\mathrm{B}$ and $\mathrm{E}$ were provided with a gelcoat. Firstly, the flexural test was realized according to ISO $178 .{ }^{7}$ With respect to the fire retardancy the oxygen index was recorded, and the tests of the flame spread and the (partial) heat release were performed using the cone calorimeter method. ${ }^{8,9}$

\section{RESULTS AND DISCUSSION}

The measured values of the mechanical properties and fire behavior are shown in Figure 1. As can be seen, the highest values for both flexural properties of the samples prepared with the wet technology were obtained 
Table 2: Material characterization of composite materials

Tabela 2: Karakterizacija materialov v kompozitu

\begin{tabular}{|c|c|c|c|c|c|}
\hline Material description & Sample A & Sample B & Sample C & Sample D & Sample E \\
\hline Reinforcement lay-up & $\begin{array}{l}1 \times \text { BIDI glass } \\
\text { fabric* } \\
1 \times \text { CGM } * * \\
1 \times \text { BIDI glass } \\
\text { fabric* }\end{array}$ & $\begin{array}{l}1 \times \text { BIDI glass } \\
\text { fabric* } \\
1 \times \mathrm{CGM}^{* *} \\
1 \times \text { BIDI glass } \\
\text { fabric* }\end{array}$ & $\begin{array}{l}1 \times \mathrm{BIDl} \text { glass } \\
\text { fabric* } \\
1 \times \mathrm{CGM}^{* *} \\
1 \times \mathrm{BIDI} \text { glass } \\
\text { fabric* }\end{array}$ & $\begin{array}{l}10 \times \\
\text { phenolic/glass* } \\
\text { prepreg }\end{array}$ & $\begin{array}{l}1 \times \text { BIDI glass } \\
\text { fabric* } \\
1 \times \mathrm{CGM}^{* *} \\
1 \times \text { BIDI glass } \\
\text { fabric* }\end{array}$ \\
\hline Matrix & matrix FR4/12 & matrix FR4/12 & matrix FR4/12 & phenolic matrix & Norester 880 \\
\hline Additive & - & - & - & - & $\begin{array}{c}\text { ATH } \\
\text { (100\% to matrix) }\end{array}$ \\
\hline Coating & - & gelcoat BÜFA & - & - & gelcoat BÜFA \\
\hline Production technology & RTM & RTM & VIP & prepreg & RTM \\
\hline
\end{tabular}

(*bidiagonal glass fabric, **continuous-filament glass mat)

for Sample C. Sample D prepared from prepregs showed excellent flexural performance and fire properties compared to the samples prepared with RTM and VIP; however, these materials are very expensive.

Moreover, comparing FR4/12 to the commercial matrix, it is obvious that the obtained mechanical properties are almost twice as high as for the samples prepared from FR4/12.

The tests of the fire properties (Figure 2) showed that the gelcoat layer also influences the flame spread and the heat release. Further, the oxygen index of Samples B (matrix FR4/12) and E (the commercial matrix) was the same for both samples. Sample C exhibited the lowest oxygen index of all the produced composites. Regarding the requirement for the oxygen index (higher than 30), all the samples passed the test. The heat-release parameter (Figure 3) was measured only for Samples A, $\mathrm{B}$ and $\mathrm{C}$, where individual values were $211.6,154.7$ and 37.7. The curves in Figure 3 show the heat release during the combustion of the samples. The flame spread (Figure 4) for Samples A and C is the same (due to the same material composition).

\section{CONCLUSION}

The main objective of the mechanical testing was to determine whether the strengths of the material combinations reached $150 \mathrm{MPa}$ (this value is the requirement

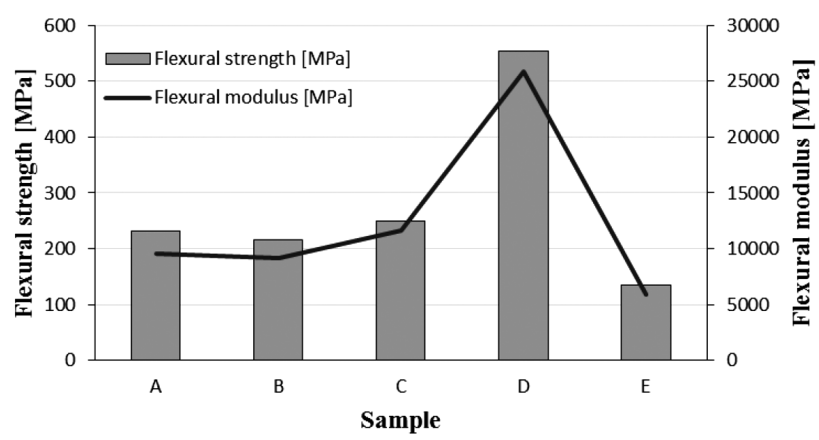

Figure 1: Flexural properties of prepared samples Slika 1: Upogibne lastnosti pripravljenih vzorcev

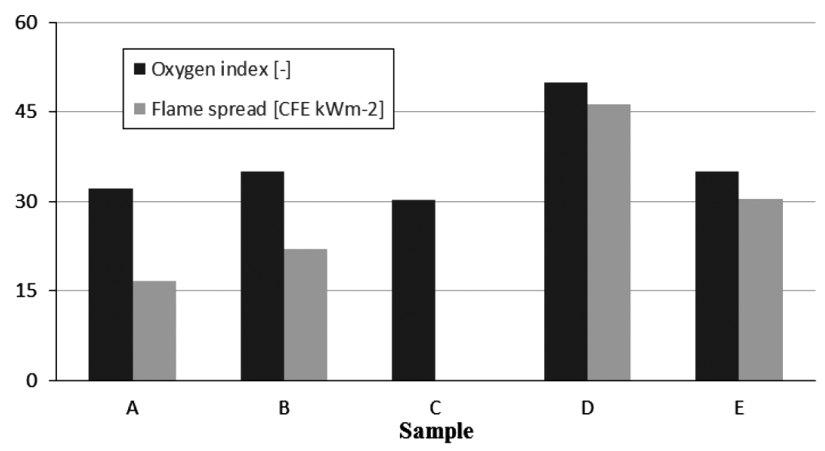

Figure 2: Fire properties of prepared samples Slika 2: Požarne lastnosti pripravljenih vzorcev
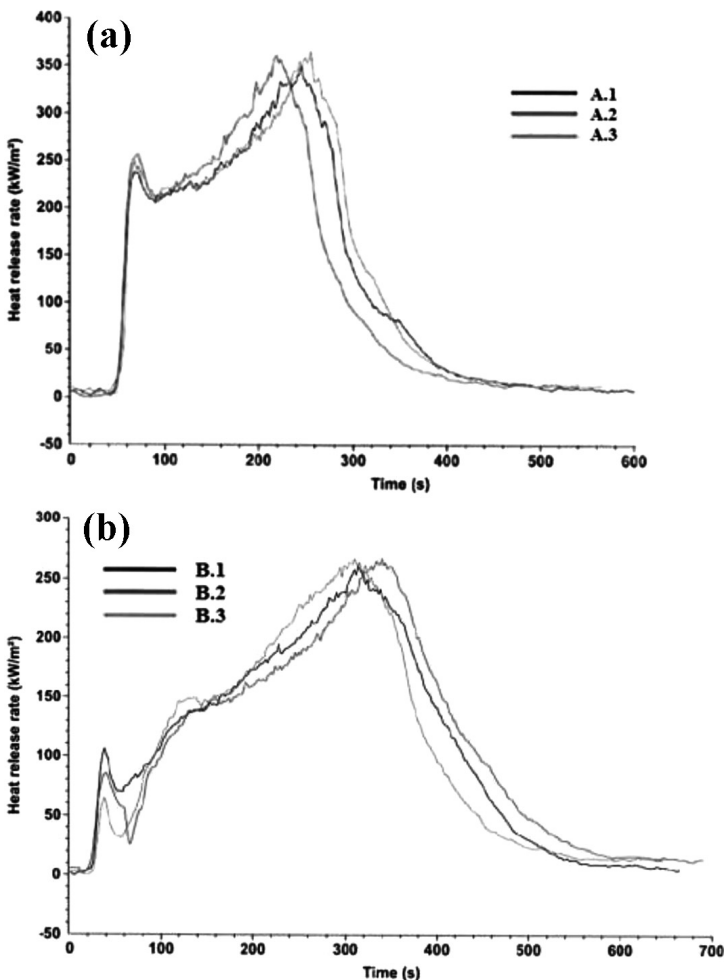

Figure 3: Heat release during the flame test of composite materials: a) sample A, b) sample B

Slika 3: Sproščanje toplote pri preizkusu kompozitnega materiala $\mathrm{v}$ plamenu: a) vzorec A, b) vzorec B 
Table 3: Table guide to selecting the test classification ${ }^{1}$

Tabela 3: Tabelarni napotek za izbiro klasifikacije preizkusa ${ }^{1}$

\begin{tabular}{|c|c|c|c|c|c|c|c|c|}
\hline $\begin{array}{l}\text { ASTM 2863: LIMITED } \\
\text { OXYGEN INDEX (LOI) }\end{array}$ & $\begin{array}{c}\text { UK: } \\
\text { BS 476 } \\
\text { PART 6,7 }\end{array}$ & \multicolumn{2}{|c|}{$\begin{array}{l}\text { GERMANY: } \\
41025510\end{array}$} & \multicolumn{2}{|c|}{$\begin{array}{l}\text { FRANCE: } \\
\text { NF P 92-501 }\end{array}$} & \multicolumn{2}{|c|}{$\begin{array}{l}\text { USA: ASTM E84 } \\
\text { UL94 }\end{array}$} & $\begin{array}{l}\text { EUROCLASS: SINGLE } \\
\text { BURNING ITEM (SBI) }\end{array}$ \\
\hline $41-50$ & Class 0 & Class A2 & $\mathrm{S} 4$ & M1 & 25 & $5 \mathrm{~V}$ & 0 & B \\
\hline $34.5-41$ & Class 1 & Class B1 & $\mathrm{S} 4$ & M2 & 50 & 0 & 1 & $\mathrm{~B} / \mathrm{C}$ \\
\hline $28.5-34.5$ & Class 2 & Class B2 & S3 & M3 & 100 & 0 & 2 & $\mathrm{C} / \mathrm{D}$ \\
\hline $22-28.5$ & Class 3 & Class B3 & $\mathrm{S} 2$ & M4 & $>100$ & 1 & 3 & $\mathrm{D} / \mathrm{E}$ \\
\hline
\end{tabular}
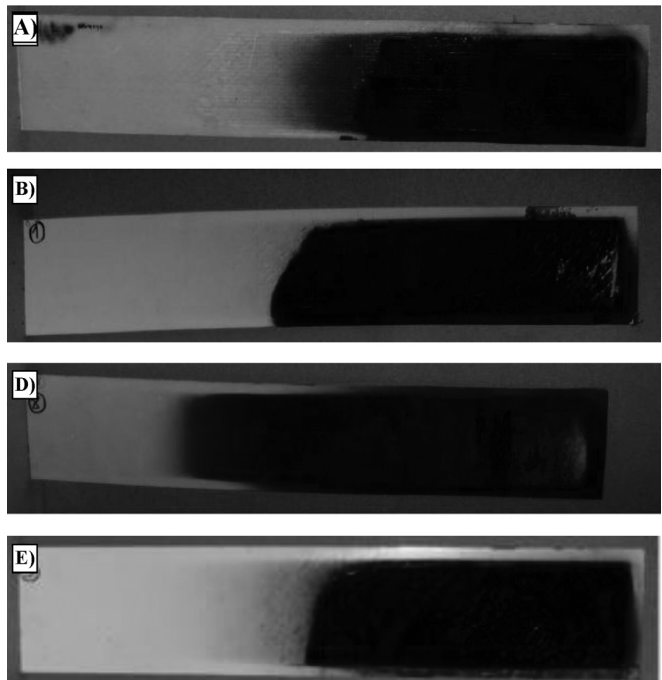

Figure 4: Composite samples after the flame-spread test Slika 4: Kompozitni vzorci po preizkusu širjenja ognja

of French standard NF F01-281). All the material combinations met this requirement with a certain safety margin, except for Sample E. The result was expressed with a high amount of the filler in the resin (the ratio of $1: 1)$. It is obvious that after adding the additives the value of the bending strength decreases.

The objective of testing the fire resistance of the materials was to determine the level of the flame retardancy of the composites made from the new matrix system. Using a simple test - determination of the oxygen index - the materials could be classified into the mid-level category of flame-retardant resins. It was assumed that with the addition of non-reactive additives the oxygen index, together with the overall resistance to fire, would increase. According to all the flame-retardancy tests, the flame-retardant gelcoat plays an important role in improving the fire resistance.

The oxygen index (Table 3) for various composites based on the new matrix is very similar to the oxygen index of pure resin. Increasing the glass amount has a minimum impact on the oxygen index. However, it is assumed that with the additions of non-reactive additives to a composite system, the oxygen index will increase. The values of the heat release for the phenolic systems are relatively large in comparison with the values for the composite systems based on the new matrix.
The developed matrix exhibits excellent processing properties, good and fast fiber wetting, adjustable reactivity and curing times. Another advantage is that the used promoter is based on iron compounds.

From the overview of the properties of all the systems, it is clear that the polyester systems do not reach the same fire-resistance values as the phenolic systems. On the other hand, due to other advantages (surface quality, price and processing methods) the development of the composite systems based on polyester systems will dominate.

\section{Acknowledgement}

This work and the project were realized with the financial support of the Ministry of Industry and Trade of the Czech Republic, project number FR-T13/433. Further, this study was also supported by an internal grant of TBU in Zlín, No. IGA/FT/2015/001, funded from the resources for specific university research.

\section{REFERENCES}

${ }^{1}$ Fire retardant polyester systems, Product guide of the Reichhold company

${ }^{2}$ N. Sain, S. H. Park, F. Suhara, S. Law, Flame retardant and mechanical properties of natural fibre-PP composites containing magnesium hydroxide, Polymer Degradation and Stability, 83 (2004), 363-367, doi:10.1016/S0141-3910(03)00280-5

${ }^{3}$ A. Genovese, R. A. Shanks, Structural and thermal interpretation of the synergy and interactions between the fire retardants magnesium hydroxide and zinc borate, Polymer Degradation and Stability, 92 (2007) 1, 2-13, doi:10.1016/j.polymdegradstab.2006.10.006

${ }^{4}$ A. P. Mouritz, A. G. Gibson, Fire properties of polymer composite materials, vol. 143, Springer, Netherlands 2006, 401, doi:10.1007/ 978-1-4020-5356-6

${ }^{5}$ G. E. Zaikov, S. M. Lomakin, S. V. Usachev, E. V. Koverzanova, N. G. Shilkina, L. V. Ruban, New Approaches to Reduce Plastic Combustibility, In: A. K. Kulshreshtha, C. Vasile (Eds.), Handbook of Polymer Blends and Composites, Volume 2, Smithers Rapra Technology, UK 2002, 165-199

${ }^{6}$ EN ISO 2555:1989, Plastics, Resins in the liquid state or as emulsions or dispersions, Determination of apparent viscosity by the Brookfield Test method, 1989

${ }^{7}$ ISO 178:2010, Plastics, Determination of flexural properties, 2010

${ }^{8}$ EN ISO 4589-2:1999, Plastics, Determination of burning behaviour by oxygen index, Ambient-temperature test, 1999

${ }^{9}$ ISO 5658-2:2006, Reaction to fire tests, Spread of flame - Part 2: Lateral spread on building and transport products in vertical configuration, 2006 